\title{
ECOLOGICAL-ECONOMIC MODELLING TO MAINTAIN MAXIMUM ALLOWABLE DISCHARGE OF SUBSTANSES INTO THE WATER BODY
}

\author{
Anna Severina \\ A.I. Shishkin \\ St.-Petersburg State Polytechnic University, Russia
}

\begin{abstract}
Today administrative mechanisms of ecological management are primary in Russia. Their inefficiency is defined by absence of advancing influence and the due control. These mechanisms, as a rule, start to operate when negative influence is already made and harm to the environment is done. The work urgency is caused by the sharpness of the water legislation and regulation problems in Russia, as this sphere is the crossroads of all industrial, agricultural interests and also providing good life conditions for the population. The urgency of ecological-economic modelling is caused by rapid development of ecological management systems in the last years. That is stimulated by the aspiration of market participants to raise management efficiency of the enterprises, to lower power and resources consumption, to raise the quality of goods and services, to create more comfortable working conditions, to provide safety of the personnel and, as a result, to improve the reputation and to raise their competitive advantages.
\end{abstract}

The purpose of the work is to draw up and to deicide a problem of ecological-economic optimization within the limits of linear programming for a "water user - water body" system. Such a linear programming problem is similar to the model of investment projects choice. The problem's solution is based on searching the best, from the economic point of view, sewage treat system to maintain maximum allowable discharge of substances into the water body.

\section{KEYWORDS}

Ecological-economic modeling; Maximum allowable discharge; Sewage treat system; Linear programming problem.

\section{INTRODUCTION}

The basic scopes of ecological-economic modeling, as the basic research method of economy of environmental economics, are:

- working out of the indicators characterizing quality of environment,

- forecasting of possible environmental changes as a result of acceptance of various (mainly, economic) decisions,

- forecasting of feedback effect of ecological factors for manufacture and economic processes as a whole, 
- environmental management planning (for example, waste treatment plants construction, creation of non-waste technologies).

Such problems of ecological-economic optimization as the water charge optimization [1], the assessment of environmental measures for water bodies protection taking into account economic and ecological requirements [2] and others can be solved by means of ecologicalmathematical modeling methods.

The major principle of ecological-economic modeling is the minimax principle: in all cases the use of natural resources, improvement of one or other environmental objects (for example, water or air pollution elimination) should bring the maximum social utility at the minimum corresponding activity costs. Particularly, the comparison of environment improvement costs or pollutants elimination costs with the received ecological benefit can act as an optimality criterion.

Various measures can be used when working out the water protection program. These measures possess different indicators of ecological efficiency and various costs for their realization, all that requires an ecological-economic optimization problem statement. Mathematically an optimization problem statement for a "water user - water body" system means the following: it is required to choose such a complex of the water protection measures providing set effluent standards of harmful substances, at which the sum of water-protective measures realization costs (building or reconstruction of a water protection structure) tends to a minimum.

\section{ADAPTATION OF AN INVESTMENT PROJECTS OPTIMUM CHOICE PROBLEM TO THE ECOLOGICAL-ECONOMIC MODELING CONDITIONS}

It has been noticed by the author that the ecological-economic optimization problem to maintain maximum allowable discharge of substances into a water body can be presented in the form of a mathematical model similar to the model about the choice of investment projects within the limits of linear programming [3]. An investment projects optimum choice problem adaptation to the specified conditions taking into account the input of restrictive criteria in the form of effluent standards (maximum allowable discharge) is presented by table 1 and system (1) located lower.

Table 1.Linear programming problem parameters.

\begin{tabular}{|c|c|c|c|c|c|}
\hline \multirow{2}{*}{$\begin{array}{l}\text { Environmental } \\
\text { action }\end{array}$} & \multicolumn{4}{|c|}{ Polluting substances } & \multirow{2}{*}{$\begin{array}{c}\text { Effluent } \\
\text { treatment } \\
\text { costs }\end{array}$} \\
\hline & 1 & 2 & $\ldots$ & $\mathrm{m}$ & \\
\hline 1 & $\mathrm{~V}_{11}$ & $\mathrm{~V}_{12}$ & & $\mathrm{~V}_{1 \mathrm{~m}}$ & $\mathrm{~S}_{1}$ \\
\hline 2 & $\mathrm{~V}_{21}$ & $\mathrm{~V}_{22}$ & & $\mathrm{~V}_{2 \mathrm{~m}}$ & $\mathrm{~S}_{2}$ \\
\hline$\ldots$ & $\ldots$ & $\ldots$ & $\ldots$ & $\ldots$ & $\ldots$ \\
\hline $\mathrm{n}$ & $\mathrm{V}_{\mathrm{n} 1}$ & $\mathrm{~V}_{\mathrm{n} 2}$ & & $\mathrm{~V}_{\mathrm{nm}}$ & $\mathrm{S}_{\mathrm{n}}$ \\
\hline MPD & $\mathrm{V}_{1}^{*}$ & $\mathrm{~V}_{2}^{*}$ & & $\mathrm{~V}_{\mathrm{m}}{ }^{*}$ & \\
\hline
\end{tabular}




$$
\left\{\begin{array}{l}
S=\sum_{i=1}^{n} S_{i} \cdot x_{i} \rightarrow \min \\
\sum_{i=1}^{n} V_{i j} \cdot x_{i} \leq V_{j}^{*} \\
\sum_{i=1}^{n} x_{i}=1 \\
x_{i} \in\{0,1\} \\
i=\overline{1, n} \\
j=\overline{1, m}
\end{array}\right.
$$

Variables $X_{i}$ represent various actions (effluent treatment systems, and also their combinations) which can be applied at an enterprise for the industrial waste waters treatment to maintain maximum permissible discharge (MPD) of substances. $X_{i}$ are binary variables which can accept only two values ( 1 and 0$)$ depending on, whether the effluent standards are provided at the choice of the $i$-th action $\left(X_{i}=1\right)$ or not $\left(X_{i}=0\right)$.

$S$ - the objective function minimizing effluent treatment costs $\left(S_{i}\right)$, its coefficients are rated according to the formula:

$$
S_{i}=\Sigma \alpha_{i j} q_{j} \beta_{i j}
$$

where $\alpha_{i j}$ - the cleaning up cost of a mass unit of the $j$-th substance within the limits of the $i$ th action - is got for each technology of effluent treatment by taking account of capital and operating costs; $q_{j}$ - the mass of polluting substances dumped into the water body - actual discharge for each polluting substance; $\beta_{i j}$ - a part of discharged mass which is cleaned up the effectiveness index of the $j$-th substance treatment within the limits of the $i$-th action.

Coefficients at variables from inequalities-constraints which represent the dumped mass of the $j$-th substance after the realization of the $i$-th action, are rated according to the formula:

$$
V_{i j}=q_{j}\left(1-\beta_{i j}\right)
$$

Constants in the left parts of inequalities $\left(V_{j}^{*}\right)$ - maximum permissible discharge (MPD) of the $j$-th polluting substance.

The result of solving an optimization problem within the limits of linear programming is the choice of the one optimal action for waste water's cleaning up that is provided with the introduction of the following equation into the systems of constraints: $\sum_{i=1}^{n} x_{i}=1$. Such an action for waste water's cleaning up, in comparison with others considered, will have the least cost at the maintenance of all polluting substances' effluent standards expressed in inequalities-constraints. The problem will have the solution in case at least one of actions satisfies all inequalities-restrictions of system (1).

2 THE SEARCH OF AN OPTIMUM VARIANT OF SEWAGE TREAT SYSTEM FOR MAINTENANCE OF MAXIMUM PERMISSIBLE DISCHARGE NORMS ON THE EXAMPLE OF THE SYSTEM «MUE "ПЖЭT"- THE IZHORA RIVER» 
MUE "ПЖЭТ" - the municipal unitary enterprise which is situated in the town of Communar in the St.-Petersburg region and dumps its waste waters into the Izhora river which is the left tributary of the Neva river. There is the excess of permissible discharge in following substances of its waste waters: suspended solids - 30\%, ultimate BOD $-378 \%$, total phosphorus - $108 \%$, ammonium nitrogen - $933 \%$, total nitrogen - $117 \%$.

The following actions can be carried out to decrease the discharged mass of these polluting substances at the enterprise: 1 - replacement of the aeration system; 2 - realization of 5-zonal aeration system with the replacement of the existing aeration system to fine-bubble; 3 replacement of the aeration system, realization nitrate and anoxic recirculation of mixed liquor, installation of mechanical mixing devices; 4 - afterpurification at sand filters; 5 afterpurification at biofilters; 6 - disinfection by chlorine. Effectiveness of the given actions, and also actual and standard characteristics of the enterprise's waste waters about five mentioned above polluting substances are presented in table 2.

Table 2.Effluent treatment effectiveness, actual mass of dump and maximum permissible discharge of MUE "ПЖЭT".

\begin{tabular}{|c|c|c|c|c|c|c|}
\hline \multirow[b]{2}{*}{$\begin{array}{l}\text { Action } \\
\text { number }\end{array}$} & \multirow{2}{*}{$\begin{array}{c}\text { Effluent } \\
\text { treatment } \\
\text { costs, } \\
\text { Si, mln. rubles }\end{array}$} & \multicolumn{5}{|c|}{ Effectiveness, $\beta_{i j}, \%$} \\
\hline & & $\begin{array}{l}\text { suspended } \\
\text { solids }\end{array}$ & $\begin{array}{c}\text { ultimate } \\
\text { BOD }\end{array}$ & $\begin{array}{c}\text { total } \\
\text { phosphorus }\end{array}$ & $\begin{array}{l}\text { ammonium } \\
\text { nitrogen }\end{array}$ & $\begin{array}{c}\text { total } \\
\text { nitrogen }\end{array}$ \\
\hline 1 & 1 & 77 & 83 & - & - & - \\
\hline 2 & 2 & 82 & 92 & 55 & 97 & 52 \\
\hline 3 & 10 & 89 & 97 & 33 & 97 & 52 \\
\hline 4 & 200 & 85 & 80 & - & 80 & 40 \\
\hline 5 & 250 & 85 & 85 & 50 & 90 & 60 \\
\hline 6 & 150 & - & 80 & - & - & - \\
\hline \multicolumn{2}{|c|}{$\begin{array}{l}\text { Actual mass of dump, } q_{j} \text {, } \\
\text { ton per annum }\end{array}$} & 75,6 & 97,7 & 5,4736 & 45,657 & 49,929 \\
\hline \multicolumn{2}{|c|}{ MPD,$V_{j}^{*}$, ton per annum } & 58,056 & 20,447 & 2,624 & 4,418 & 22,954 \\
\hline
\end{tabular}

Twenty three possible combinations of 6 variants mentioned before actions for sewage treatment were analyzed to make the statement of a linear programming problem for the optimum choice of the clearing up action to maintain the norms of maximum permissible discharge. These combinations are represented by variables $X_{i}$ from the system of equations and inequalities (1). The dumped masses ( $V_{i j}$, ton per annum) of 5 mentioned above polluting substances after waste waters' cleaning up using each of 23 possible variants and also the their costs are presented in table 3.

Thus in tables 2 and 3 there are values of all parameters from system (1) that makes it possible to solve a linear programming problem and to choose one optimum variant from 23 
combinations of sewage treatment methods which has the least cost and provides the achievement of maximum permissible discharge norms.

Table 3

The dumped masses of polluting substances after the realization of cleaning up actions.

\begin{tabular}{|c|c|c|c|c|c|c|c|}
\hline \multirow{2}{*}{$\begin{array}{c}\text { Variables } \\
X_{i}\end{array}$} & \multirow{2}{*}{$\begin{array}{l}\text { Action } \\
\text { number }\end{array}$} & \multirow{2}{*}{$\begin{array}{c}S i \\
\text { mln. } \\
\text { rubles }\end{array}$} & \multicolumn{5}{|c|}{$V_{i j}$, ton per annum } \\
\hline & & & $\begin{array}{l}\text { suspended } \\
\text { solids }\end{array}$ & $\begin{array}{c}\text { ultimate } \\
\text { BOD }\end{array}$ & $\begin{array}{c}\text { total } \\
\text { phosphorus }\end{array}$ & $\begin{array}{c}\text { ammonium } \\
\text { nitrogen }\end{array}$ & $\begin{array}{c}\text { total } \\
\text { nitrogen }\end{array}$ \\
\hline$X_{1}$ & 1 & 1 & 17,388 & 16,609 & 5,474 & 45,657 & 49,929 \\
\hline$X_{2}$ & 2 & 2 & 13,608 & 7,816 & 2,463 & 1,370 & 23,966 \\
\hline$X_{3}$ & 3 & 10 & 8,316 & 2,931 & 3,667 & 1,370 & 23,966 \\
\hline$X_{4}$ & 4 & 200 & 11,340 & 19,540 & 5,474 & 9,131 & 29,957 \\
\hline$X_{5}$ & 5 & 250 & 11,340 & 14,655 & 2,737 & 4,566 & 19,972 \\
\hline$X_{6}$ & 6 & 150 & 75,600 & 19,540 & 5,474 & 45,657 & 49,929 \\
\hline$X_{7}$ & $1+4$ & 201 & 2,608 & 3,322 & 5,474 & 9,131 & 29,957 \\
\hline$X_{8}$ & $1+5$ & 251 & 2,608 & 2,491 & 2,737 & 4,566 & 19,972 \\
\hline$X_{9}$ & $1+6$ & 151 & 17,388 & 3,322 & 5,474 & 45,657 & 49,929 \\
\hline$X_{10}$ & $2+4$ & 202 & 2,041 & 1,563 & 2,463 & 0,274 & 14,380 \\
\hline$X_{11}$ & $2+5$ & 252 & 2,041 & 1,172 & 1,232 & 1,233 & 9,586 \\
\hline$X_{12}$ & $2+6$ & 152 & 13,608 & 1,563 & 2,463 & 1,370 & 23,966 \\
\hline$X_{13}$ & $3+4$ & 210 & 1,247 & 0,586 & 3,667 & 0,274 & 14,380 \\
\hline$X_{14}$ & $3+5$ & 260 & 1,247 & 0,440 & 1,834 & 0,137 & 9,586 \\
\hline$X_{15}$ & $3+6$ & 160 & 8,316 & 0,586 & 3,667 & 1,370 & 23,966 \\
\hline$X_{16}$ & $4+6$ & 350 & 11,340 & 3,908 & 5,474 & 9,131 & 29,957 \\
\hline$X_{17}$ & $5+6$ & 400 & 11,340 & 2,931 & 2,737 & 4,566 & 19,972 \\
\hline$X_{18}$ & $1+4+6$ & 351 & 2,608 & 0,664 & 5,474 & 9,131 & 29,957 \\
\hline$X_{19}$ & $1+5+6$ & 401 & 2,608 & 0,498 & 2,737 & 4,566 & 19,972 \\
\hline$X_{20}$ & $2+4+6$ & 352 & 2,041 & 0,313 & 2,463 & 0,274 & 14,380 \\
\hline$X_{21}$ & $2+5+6$ & 402 & 2,041 & 0,234 & 1,232 & 0,137 & 9,586 \\
\hline$X_{22}$ & $3+4+6$ & 360 & 1,247 & 0,117 & 3,667 & 0,274 & 14,380 \\
\hline$X_{23}$ & $3+5+6$ & 410 & 1,247 & 0,088 & 1,834 & 0,137 & 9,586 \\
\hline
\end{tabular}

\section{SOLVING THE LINEAR PROGRAMMING PROBLEM USING WINQSB PROGRAM}

Such a linear programming problem can be solved using WINQSB program. Figure 1 shows the input parameters window of the problem with 23 binary variables, and 5 inequalitiesconstraints, a single equation, as well as the objective function aimed at a minimum.

The option "Solve the Problem" is selected after entering all the parameters of the problem in matrix form. Here the problem is solved by branch and bound method, if at least one of variables is defined as a whole or binary variable. At the end of the decision appears that the problem is solved and either the optimal solution is achieved, or the problem is infeasible, or 
Linnaeus ECO-TECH '10

Kalmar, Sweden, November 22-24, 2010

the objective function is not limited (the problem is unbounded) [4]. The results of solving the problem are reflected in the summary report, shown by figure 2 .

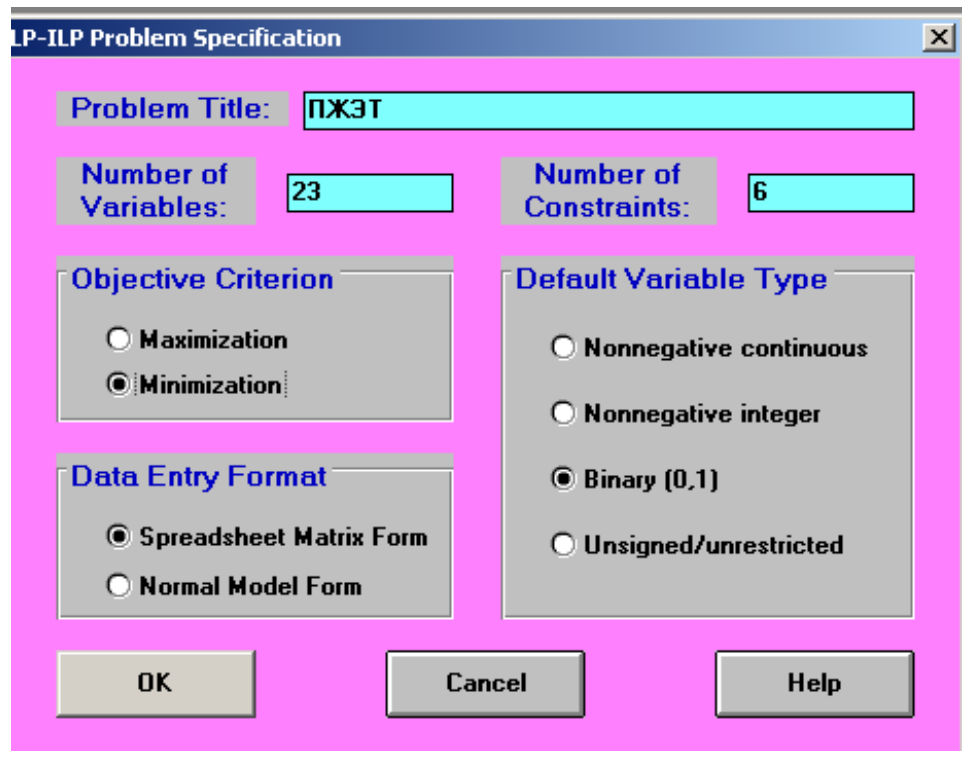

Figure 1. Entering settings for solving the linear programming problem. 


\begin{tabular}{|c|c|c|c|c|c|c|}
\hline & $\begin{array}{l}\text { Decision } \\
\text { Variable }\end{array}$ & $\begin{array}{l}\text { Solution } \\
\text { Value }\end{array}$ & $\begin{array}{l}\text { Unit Cost or } \\
\text { Profit c(i) }\end{array}$ & $\begin{array}{c}\text { Total } \\
\text { Contribution }\end{array}$ & $\begin{array}{c}\text { Reduced } \\
\text { Cost }\end{array}$ & $\begin{array}{l}\text { Basis } \\
\text { Status }\end{array}$ \\
\hline 1 & $x 1$ & 0 & 1,0000 & 0 & 1,0000 & at bound \\
\hline 2 & $\times 2$ & 0 & 2,0000 & 0 & 2,0000 & at bound \\
\hline 3 & $\times 3$ & $\mathbf{0}$ & 10,0000 & $\mathbf{0}$ & 10,0000 & at bound \\
\hline 4 & $\times 4$ & 0 & 200,0000 & 0 & 50,0000 & at bound \\
\hline 5 & $\times 5$ & 0 & 250,0000 & $\mathbf{0}$ & 100,0000 & at bound \\
\hline 6 & $\times 6$ & 0 & 150,0000 & $\mathbf{0}$ & $\mathbf{0}$ & basic \\
\hline 7 & $x 7$ & 0 & 201,0000 & $\mathbf{0}$ & 51,0000 & at bound \\
\hline 8 & $\times 8$ & $\mathbf{0}$ & 251,0000 & $\mathbf{0}$ & 101,0000 & at bound \\
\hline 9 & $\times 9$ & 0 & 151,0000 & $\mathbf{0}$ & 1,0000 & at bound \\
\hline 10 & $\times 10$ & 1,0000 & 202,0000 & 202,0000 & 202,0000 & at bound \\
\hline 11 & $\times 11$ & 0 & 252,0000 & $\mathbf{0}$ & 102,0000 & at bound \\
\hline 12 & $\times 12$ & 0 & 152,0000 & $\mathbf{0}$ & 2,0000 & at bound \\
\hline 13 & $\times 13$ & 0 & 210,0000 & $\mathbf{0}$ & 60,0000 & at bound \\
\hline 14 & $\times 14$ & 0 & 260,0000 & 0 & 110,0000 & at bound \\
\hline 15 & $\times 15$ & $\mathbf{0}$ & 160,0000 & $\mathbf{0}$ & 10,0000 & at bound \\
\hline 16 & $\times 16$ & 0 & 350,0000 & $\mathbf{0}$ & 200,0000 & at bound \\
\hline 17 & $\times 17$ & 0 & 400,0000 & $\mathbf{0}$ & 250,0000 & at bound \\
\hline 18 & $\times 18$ & 0 & 351,0000 & 0 & 201,0000 & at bound \\
\hline 19 & $\times 19$ & 0 & 401,0000 & $\mathbf{0}$ & 251,0000 & at bound \\
\hline 20 & $\times 20$ & 0 & 352,0000 & $\mathbf{0}$ & 202,0000 & at bound \\
\hline 21 & $\times 21$ & 0 & 402,0000 & $\mathbf{0}$ & 252,0000 & at bound \\
\hline 22 & $\times 22$ & 0 & 360,0000 & $\mathbf{0}$ & 210,0000 & at bound \\
\hline \multirow[t]{3}{*}{23} & $\times 23$ & 0 & 410,0000 & 0 & 260,0000 & at bound \\
\hline & Objective & Function & [Min.] = & 202,0000 & & \\
\hline & Constraint & $\begin{array}{l}\text { Left Hand } \\
\text { Side }\end{array}$ & Direction & $\begin{array}{c}\text { Right Hand } \\
\text { Side }\end{array}$ & $\begin{array}{c}\text { Slack } \\
\text { or Surplus }\end{array}$ & $\begin{array}{l}\text { Shadow } \\
\text { Price }\end{array}$ \\
\hline 1 & C1 & 2,0412 & $<=$ & 58,0560 & 56,0148 & 0 \\
\hline 2 & $\mathrm{C} 2$ & 1,5632 & $<=$ & 20,4470 & 18,8838 & $\mathbf{0}$ \\
\hline 3 & C3 & 2,4631 & $<=$ & 2,6240 & 0,1609 & $\mathbf{0}$ \\
\hline 4 & C4 & 0,2739 & $<=$ & 4,4180 & 4,1441 & 0 \\
\hline 5 & C5 & 14,3796 & $<=$ & 22,9540 & 8,5744 & $\mathbf{0}$ \\
\hline 6 & C6 & 1,0000 & $=$ & 1,0000 & $\mathbf{0}$ & 150,0000 \\
\hline
\end{tabular}

Figure 2. Summary report on solving the linear programming problem.

\section{RESULTS}

From the summary report of solving ecological-economic optimization problem in linear programming to choose an optimal sewage treat system (figure 2) we can conclude the following: the variant number $10\left(X_{10}=1\right)$ is considered to be the optimal action for the enterprise MUE “ПЖЭТ” sewage treatment.

Under the variable $X_{10}$ was encrypted the combination of cleaning up methods (2+4): $2-$ realization of 5-zonal aeration system with the replacement of the existing aeration system to fine-bubble, 4 - afterpurification at sand filters. The cost of this action will be 202 million rubles $(4926829 €)$.

\section{CONCLUSIONS}

Considered in this article model can be applied for making management decisions regarding the selection of the enterprise's optimal policy in the sphere of sewage treatment, as well as to 
achieve the specified quality parameters of effluent (maximum permissible discharge). In the case of a large selection of processing methods for sewage treatment the model allows to choose the best variant, taking into account two main criteria: the sufficient purification efficiency to achieve the effluent standards and the minimum cost of implementation.

\section{REFERENCES}

[1] Glukhov V.V., Nekrasova T.P. Economic foundations of ecology - 3rd ed.- St. Petersburg: Piter, $2003-383$.

[2] Shishkin A.I., Severina A.V., Sophijskaya E.Y. Ecological-economic modeling in the system "user of water user-water body" / / Abstracts of scientific conference. Prediction and prevention problems of emergencies and their consequences. - St. Petersburg: University ETU "LETI", 2007 - 107-112.

[3] Yuriev V.N., Optimization methods in economics and management - St. Petersburg: Polytechnic Univ. Press, 2006 - 37-38.

[4] Kutuzov A.L., Mathematical methods and models of operations research. Linear optimization with WinQSB and Excel - St. Petersburg: Polytechnic Univ., 2004. - 88. 